\title{
Presence or Absence of Cognitive Partnership in Early School Education: Research Report
}

\section{(Nie)obecność partnerstwa poznawczego w edukacji wczesnoszkolnej. Komunikat z badań}

\section{KEYWORDS ABSTRACT}

early school The main aim of the article is to present the results of preliminary education, cognitive qualitative research on the ways in which teachers of grades 1-3 of partnership, teachers' primary school understand cognitive partnership and the meanings convictions they assign to it in their own school practice. The method of individual open-ended interview was used in the research.

On the basis of the obtained research results, it can be concluded that, in the opinion of the respondents, cognitive partnership is possible and even necessary in early school education. The teachers' declarations show that cognitive partnership is present in their educational activities, but it is impossible to fully implement it due to the cognitive developmental features of children at the early school age. The vast majority of the respondents, when explaining the discussed concept, focused in their statements primarily on the intellectual aspect of cognitive partnership, but the importance of social relations between the teacher and the student/students in the process of gaining knowledge was emphasized less frequently. When explaining the concept of cognitive partnership, the surveyed teachers most often focused unilaterally either on the teacher's actions or on the child's activities that indicate cognitive partnership. The understanding of the discussed concept as a system of relations between the subjects of education, who co-decide about the course and effects of the education process, 
occurred much less frequently. The obtained results are a contribution to conducting further in-depth research, especially with regard to the place and manner of implementing the idea of cognitive partnership in the practice of early school education.

\section{poznawcze, przekonania nauczycieli}

SŁOWA KLUCZE ABSTRAKT

edukacja Jednym z kluczowych czynników warunkujących przygotowanie wczesnoszkolna, dziecka do wyzwań, jakie stawia przed nim dynamicznie zmieniająca partnerstwo się rzeczywistość, jest partnerstwo poznawcze w edukacji. Głównym celem artykułu jest przedstawienie wyników wstępnych badań jakościowych nad sposobami rozumienia partnerstwa poznawczego przez nauczycieli klas I-III szkoły podstawowej oraz znaczenia, jakie mu przypisują we własnej praktyce szkolnej. W badaniu zastosowano metodę indywidualnego wywiadu otwartego.

$\mathrm{Na}$ podstawie uzyskanych wyników badań można stwierdzić, że w ocenie badanych partnerstwo poznawcze jest możliwe, a nawet konieczne w edukacji wczesnoszkolnej. Z deklaracji nauczycieli wynika, że partnerstwo poznawcze jest obecne w ich działaniach edukacyjnych, lecz niemożliwe w pełni do realizacji ze względu na cechy rozwoju poznawczego dzieci w młodszym wieku szkolnym. Zdecydowana większość respondentów dokonując wyjaśnienia omawianego pojęcia skoncentrowała się w swoich wypowiedziach przede wszystkim na aspekcie intelektualnym partnerstwa poznawczego, rzadziej natomiast podkreślano znaczenie relacji społecznych między nauczycielem i uczniem/ uczniami w procesie dochodzenia do wiedzy. Wyjaśniając pojęcie partnerstwa poznawczego badani nauczyciele najczęściej koncentrowali się jednostronnie albo na działaniach nauczyciela, albo na czynnościach dziecka, które wskazują na partnerstwo poznawcze. Znacznie rzadziej ujawniało się rozumienie omawianego pojęcia jako układu relacji między podmiotami kształcenia, które współdecydują o przebiegu i efektach procesu kształcenia. Uzyskane wyniki stanowią przyczynek do prowadzenia dalszych pogłębionych badań, zwłaszcza w odniesieniu do miejsca i sposobu realizacji idei partnerstwa poznawczego w praktyce edukacji wczesnoszkolnej.

\section{Introduction}

One of the basic challenges of modern education is the search for a school model whose activity is aimed at "the development of the individual as well as the community, taking into account the social and intellectual capital represented by them as the primary factors of change and civilization continuity" (Bałachowicz 2017: 16). The main challenge faced by schools today is educating an individual who is constantly learning, ready to take on new challenges, flexible, and easily adapting to changing 
conditions and expectations (Nowak 2007). In the context of dynamic changes in the socio-cultural reality and technological development, it is particularly important to develop students' cognitive competencies at every stage of education, which allow people to "see what is happening around them, supplement the obtained image of the world with their own experience and predict what may happen" (Obuchowski 2004: 54). Cognitive competencies, understood as "competencies needed to process and create information about oneself and the world, i.e., competencies conditioning the effects of reading, writing, counting, using symbols and using the acquired knowledge in cognitive and social functioning" (Uszyńska-Jarmoc 2018), along with creative competencies, play a key role in education. They engage mental activities in the process of getting to know reality through more or less effective action in it. Thanks to this, the individual not only gets to know the world, gives it meaning, but gradually builds his understanding, which facilitates his effective adaptation. Direct interactions with the outside world are both the source and the means of learning about it (Michalak 2011). Developing cognitive competencies prepares people not only to use the achievements of modern civilization but also to creatively participate in the process of its development. In this context, Tadeusz Lewowicki (1994) has been for many years postulating a change in the model of contemporary school, manifesting itself in the transition from adaptive and reproductive education to critical and creative education, stimulating innovation, creativity and changes in the surrounding world. The perspective that completes the vision of the task of education defined in this way is the development of current trends, needs and potentials in people who create it in a school where partnership is the basic value.

The extremely complex and multifaceted category of partnership fits permanently into the area of theoretical considerations and research aimed at searching for a school model tailored to the education of tomorrow. This article attempts to present the beliefs of early school education teachers about the importance and place of cognitive partnership in relations with children in their educational practice. The research concept has been embedded in an approach referring to emancipatory rationality and constructivism creators who present the vision of the child as a fully-fledged participant in educational processes, organizing and interpreting the incoming information and reorganizing the existing knowledge with the participation of adults and peers, able to discuss, express their own views, present their own projects and striving for change (Klus-Stańska 2009a). Due to the nature of the study, the article presents a fragment of preliminary qualitative research ${ }^{1}$ on the presence of cognitive partnership in early school education.

The research was carried out as part of an individual research project titled "Child as a Student in the Common Beliefs of Teachers," carried out in the 2019/2020 academic year and currently continued at the Institute of Pedagogy of the University of Bielsko-Biala. 


\section{Cognitive Partnership in the Teacher-Child Relationship}

According to a dictionary (Doroszewski 2000), the essence of partnership is the equal treatment of each other by people whose relationship is based on the principle of voluntary character, and whose goal is to run an enterprise and share its profits or losses. Partnership means equal rights and obligations, mutual respect, which obliges to learn and understand the so-called other party (Kocór 2018). Partnership understood as a social responsibility tool is a process that guarantees: voluntary participation of partners from various sectors, joint active action, social goals, investing resources, taking risks and benefits, and long-term cooperation (Ordon, Gębora 2017: 58). In addition to the above-mentioned features of partnership relations, such as reciprocity, cooperation, awareness of rights and obligations or respect, the concept of partnership occurs in the context of such terms as: dialogue, cooperation, trust, help, commitment, but also autonomy, subjectivity and responsibility. In relation to education, the discussed concept is most often understood as an upbringing partnership, a type of specific relations between three subjects: a student, a teacher and parents, who are linked by a common goal accepted by three parties, a positive emotional attitude towards each other, mutual respect, cooperation and co-responsibility (Milerski, Śliwerski 2000). In this perspective, school partnership mainly means cooperation and self-management of teachers, students and parents, and includes co-management of the education process.

In the field of education, partnership is most often analyzed in the social aspect, and much less often in the cognitive aspect. According to Dorota Klus-Stańska, cognitive partnership is based "on the symmetry of the statuses of meanings given to reality. The student's knowledge is considered worth considering and deliberating, which results from the social nature of all knowledge. Giving a sense of reality, the content of education is perceived horizontally (revealing a multitude of meanings and arguments), and not vertically (as definitely correct and incorrect)" (Klus-Stańska 2019: 17). In this sense, the basic indicator of cognitive partnership in the teacherstudent relationship is the acceptance and respect for the child's personal knowledge. In addition to the intellectual aspect, the essence of which is expressed in the dynamic relationship between personal and public knowledge, cognitive partnership also consists in building a space for communication (social aspect) and includes a personally dialogical perspective (ethical aspect) (Klus-Stańska 2019).

The basic condition for the implementation of the idea of cognitive partnership in the practice of early childhood education is to adopt the vision of the children and their learning potential in line with the assumptions of cognitive and social constructivism, in the light of which children have their own rich world of meanings and have the competencies to be active participants in the learning process, exchange of 
meanings, interpreting the world, oneself, others and the surrounding reality (NowakŁojewska 2017). Similarly, in the contemporary sociological approach to the category of childhood by William A. Corsaro (2015), the children are perceived as the active subjects simultaneously participating in the world of adults and peers with whom they negotiate, share and create culture. At the beginning of school, the child is ready for active, not passive learning. Child learning understood in this way also plays a key role in the theory of socio-cultural development by Katherine Nelson (2007). According to the American developmental psychologist, in the classroom, thanks to the externalization process, "students' minds" become elements of the outside world that can be shared by students and teachers. The child develops not only in the context of social interactions but also through these interactions.

Treating a child from the very beginning as a subject with a mind, encouraging independence, and describing the child's mental states are all important for the child's development, understanding other people and communication (Pikul-Białecka 2012). Establishing a partner relationship cognitively with a child is associated with taking into account their individual resources. Among them, the following are distinguished (Filipiak 2008: 23):

a) child's own activity,

b) susceptibility and resilience to react in a certain way to the teacher's instructions and guidance,

c) being amenable to learning (cognitive modifiability),

d) child's current developmental status, including "tacit knowledge" and the child's previous experiences and perceptions,

e) contents of the "toolbox" and the ability to use tools in action,

f) properties of the child's attention, the ability to pay attention, focus on the problem,

g) ability to follow the directions of Others.

The child's individual resources and the current developmental status imply the course of the relationship between the teacher and the student. Cognitive partnership is, first of all, a kind of relationship that enables the creation of opportunities for learning and the inclusion in the process of education of a child's cognitive space understood as "a zone where everything that is new and surprising inspires thinking and discovering. It cannot be limited by frameworks or ready-made solutions that inhibit the natural desire for independence" (Robinson, Aronica 2012: 74). The cognitive development of the student and his/her social competencies is primarily favored by situations in which the following conditions are met:

1. the condition of diversity: creating a richness of diverse social situations in the classroom, constituting the basis for various experiences of students, 
2. the condition of conformity: conformity of the information contained in the transfer with the reality outside school,

3. the condition of dialogue: the teacher's opening to out-of-school experiences of students and their relations on this subject (Klus-Stańska 2009b: 17).

Learning based on cognitive partnership is deeply personalized, i.e., the learning environment is highly sensitive to individual and group differences related to the background and experiences of students, to previously acquired knowledge, to their motivation and abilities, and provides them with personalized feedback (Dumont, Istance, Benavides 2013). For the process of acquiring and developing cognitive competencies, it is important for the teacher to organize educational situations stimulating the student to undertake various forms of activity that bring richness of experiences.

\section{Research Procedure}

One of the main factors determining the teachers' approach to the issue of cognitive partnership in education is the way it is understood and teachers convictions about its implementation in early school practice. Convictions are commonly referred to as all "mental" premises about the world that the subject feels as real (LemańskaLewandowska 2013: 15). In dictionary terms, conviction is defined as "a judgment, an opinion based on the belief that something is true or false, an established view of something; belief, view-point” (Szymczak 1979: 979). According to Magdalena Grochowalska (2012), building convictions is a process in which an individual aims to recreate hypotheses and theories that already function socially, and their formulation in practice determines the subjective interpretation of educational reality. Conviction research allows to describe the content that teachers attribute to reality in the education layer, in this case, cognitive partnership in early school education.

In order to determine the understanding and meaning which teachers assign to cognitive partnership in early school education, qualitative research was carried out using the individual open-ended interview method. Due to the adoption of the interpretative paradigm of qualitative research the research was aimed at showing different ways of thinking of early school education teachers about the essence and features of cognitive partnership and the methods they declare to implement in their work with children in grades 1-3 of primary school. For Neuman, "the most important thing in an interpretative approach is the systematic analysis of social meanings created by people in their natural conditions of functioning, with a view to understanding and interpreting how people create and understand their world in which they function" (Neuman 1994: 62). In an interpretative approach, words are data from the research on which the researcher's attention is focused. It is thanks to the respondents' statements, 
their narratives or written texts that it is possible to gain insight into the meanings given by informants to the events in which they participate (Zwiernik 2015).

In the course of the research, answers were sought to research problems formulated in the form of questions:

1. In the opinion of teachers, what is the meaning of cognitive partnership in early childhood education?

2. What importance do teachers assign to cognitive partnership in their work in grades $1-3$ of primary school?

According to the position expressed by Earl Babbie, the method of the used individual open-ended interview "is an interaction between the interviewer and the respondent. The facilitator has a general plan of action in it, but it is not a specific set of questions that should be asked in specific words and in order" (Babbie 2008: 342). The questions addressed to the respondents were open-ended. Some of them were basic questions, directly oriented towards undertaken description and conceptualization of experiencing phenomenon of cognitive partnership by the interviewee. Among them, there are questions such as: What is a cognitive partnership in education for you? How do you understand the cognitive partnership in relations with a child? Under what conditions and situations is cognitive partnership manifested in early childhood education? The remaining questions were formulated in the course of the interview and were aimed at making it easier for the respondents to thematize their experiences.

The research covered 23 teachers of early school education working in schools in the Silesia and Małopolska Provinces. They were conducted directly by the researcher between November 2019 and February 2020. Only women were among the respondents. As far as the work experience of the respondents is concerned, 8 teachers $(34.78 \%)$ have worked at school for no more than 10 years, the work experience of 10 people (43.48\%) was between 11 and 20 years, and the remaining 5 teachers $(21.74 \%)$ worked in the school for over 20 years.

As a result, the interview allowed to capture what the respondents think about reality, and not what the researcher thinks about it, only looking for confirmation of her own thesis. According to the adopted research approach, the ways of understanding the studied phenomenon expressed in the analyzed material implied categories of description determined by the researcher. They are "generalized and structured descriptions of understanding the phenomena present in the respondents' experience" (Męczkowska 2002: 18). The categories of description are selected through the condensation of topics that appear while reading the answers of the respondents. Established description categories, on the other hand, constitute the result space and then may or may not be subject to hierarchy, resulting in a structure of the description category. It should be emphasized that the discussed categories of description are always 
individual and collective at the same time, which means that the same statement may reflect various expressions of the same concept or different concepts (Jurgiel 2009).

\section{Research Results}

According to the adopted qualitative research procedure, the presentation of the results, for the purposes of this study, has been limited to the presentation of the categories of responses identified as a result of the analysis of the content of the respondents' statements in the interview, with the dominant tendencies in their selection marked. Due to the adoption of the interpretative paradigm of qualitative research, the research did not aim at considering the studied phenomenon in terms of quantity and multiplicity, which is characteristic of the quantitative approach, but at extracting the meanings and dimensions of cognitive partnership in early childhood education. The analysis of empirical material obtained as a result of research conducted on small groups of people is qualitative in nature and does not involve statistical tools. Nevertheless, the possibilities of using quantitative terms in qualitative and explanatory projects are indicated. David Silverman justifies it as follows: "Simple computational techniques can become a way of probing an entire set of data that is usually lost in intensive qualitative research" (Silverman 2008: 62).

The analysis of the content of the statements showed that all respondents emphasized the importance of cognitive partnership in early school education. In the opinion of the respondents, cognitive partnership is possible and even necessary at the discussed stage of education. The justifications for the opinions formulated by the surveyed teachers referred to the following categories of responses:

a) the need to treat the child as the subject,

b) changing the school to the one open to the needs and capabilities of children,

c) the need to trigger activity and meet the needs of the child,

d) introducing children from an early age to independence and responsibility for the learning process.

All the above-mentioned categories, based on the analysis of the answers, may prove that teachers are familiar with contemporary trends in early school education focused on the humanistic paradigm in the education of a young child, and in the case of less than half of the respondents, additionally with the importance of preparing a child for lifelong education.

All respondents declared that their functioning in the area of early school education is marked by cognitive partnership, although many statements (16 respondents) raised reservations that due to the features of development and the level of cognitive maturity, full cognitive partnership of children is impossible to implement in practice. 
An example of an expression: What the child thinks and knows about the topic is important, but we should also remember that we work with children. Their knowledge concerns those things and phenomena that they are able to know because of their cognitive abilities. In this context, the analysis of the content of the interviews leads to the conclusion that the consciousness of most of the respondents is dominated by the traditional psychological approach to the child development, expressed, inter alia, in assigning capabilities to learn and understand the world "limited by the developmental phase" and linear increase in knowledge to a child at the early school age.

The vast majority of respondents (19 interviewees), while explaining the discussed concept, focused in their statements primarily on the intellectual aspect of cognitive partnership, and less often (10 respondents) additionally on social relations between the teacher and the student in the learning process. Three basic groups of factors determining the cognitive partnership in work with a child at early school age, appearing in the respondents' statements, were distinguished. The division made is not separable and elements of statements belonging to particular groups of factors often coexisted in the interviews. The teachers' statements contained content elements related to several areas (Diagram 1).

Diagram 1. Groups of factors determining cognitive partnership in early school education as assessed by teachers

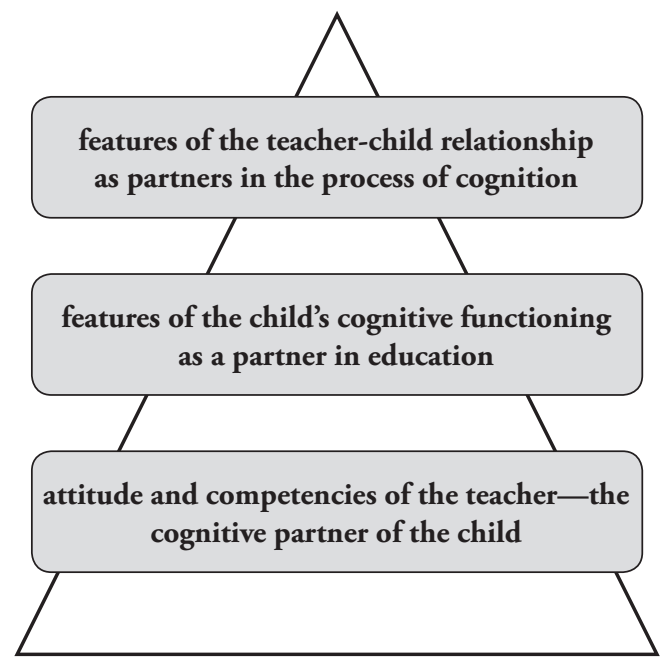

Source: Author's own elaboration. 
In their statements, all respondents pointed to the teacher's attitude and competencies, which determine the creation of space for children treated as partners in the educational process.

Table 1. Response categories defining the concept of cognitive partnership in relation to the teacher's attitude and competencies during the classes

\begin{tabular}{|c|c|c|}
\hline & Response categories & $\begin{array}{l}\text { Number of } \\
\text { indications }\end{array}$ \\
\hline \multirow{10}{*}{$\begin{array}{l}\text { Attitude and tasks } \\
\text { of the teacher- } \\
\text { the child's } \\
\text { cognitive partner }\end{array}$} & $\begin{array}{l}\text { providing support to the child according to his/her cognitive } \\
\text { needs in the learning process }\end{array}$ & 22 \\
\hline & $\begin{array}{c}\text { creating situations conducive to triggering various forms of } \\
\text { child's activity }\end{array}$ & 21 \\
\hline & $\begin{array}{l}\text { the ability to match control to the child's level of } \\
\text { development and the action taken }\end{array}$ & 20 \\
\hline & creating a friendly, safe learning atmosphere & 19 \\
\hline & $\begin{array}{l}\text { the teacher's readiness to develop the child's cognitive } \\
\text { interests }\end{array}$ & 18 \\
\hline & $\begin{array}{l}\text { the teacher's faith in the child's abilities and motivating him/ } \\
\text { her to learn }\end{array}$ & 16 \\
\hline & $\begin{array}{l}\text { accepting knowledge gaps and understanding the child's } \\
\text { difficulties in understanding things }\end{array}$ & 11 \\
\hline & $\begin{array}{l}\text { taking into account the topics and problems reported by } \\
\text { children in the classroom }\end{array}$ & 11 \\
\hline & respect and trust in the child's personal knowledge & 8 \\
\hline & posing open-ended questions during classes & 7 \\
\hline
\end{tabular}

Source: Author's own elaboration based on the results of the research.

The respondents' statements show that the presence and quality of cognitive partnership during classes in grades 1-3 of primary school is primarily influenced by the teacher's competencies and attitude towards the child. The most numerous group of responses in their statements referred to the personalization of the educational process in terms of diagnosing the needs of children's cognitive abilities and interests, as well as adjusting the methods and level of control individually to the child's needs by the teacher. An example of an expression: If you approach the children individually and understand their needs, then they open up and speak willingly. You can then find out what they know about the topic, what they think about it and what they feel. In the opinion of less than half of the respondents, cognitive partnership is expressed as the 
teacher's understanding of the problems in a child's learning and shaping a positive attitude towards learning. They attach an important role to building a child's positive self-esteem in the learning process. They recognize that a child's school success results not only from actual competencies, but also from a sense of their own competencies. In this context, it is worth emphasizing that the conducted research shows that the children's faith in themselves, their abilities, capabilities and skills have a positive effect on the results of intellectual or social functioning (Uszyńska-Jarmoc 2007). Most of the respondents emphasized the importance of the ability to create an appropriate atmosphere in the learning process and to create didactic situations comprehensively involving children, containing elements of novelty and interest.

In their statements, the surveyed teachers also indicated the features of the child's cognitive functioning, which, in their opinion, prove cognitive partnership in early childhood education.

Table 2. Response categories defining the concept of cognitive partnership in relation to the child's functioning during classes

\begin{tabular}{|c|c|c|}
\hline & Response categories & $\begin{array}{c}\text { Number of } \\
\text { indications }\end{array}$ \\
\hline \multirow{4}{*}{$\begin{array}{c}\text { Features of } \\
\text { a child's cognitive } \\
\text { functioning }\end{array}$} & child's independence in action during classes & 23 \\
\cline { 2 - 3 } & cognitive openness, motivation to acquire new knowledge & 20 \\
\cline { 2 - 3 } & child's questioning activity & 16 \\
\cline { 2 - 3 } & submitting new ideas by a child & 15 \\
\hline
\end{tabular}

Source: Author's own elaboration based on the results of the research.

According to all respondents, the essence of cognitive partnership is expressed in the child's activity and independence during classes. The respondents emphasized in their statements that the child is not a passive observer of reality and the recipient of the teacher's messages, but is a dynamically developing person in social contacts. The functioning of a child as a partner in the educational process is characterized primarily by a readiness to acquire knowledge and a cognitive attitude, which manifests itself in asking numerous questions regarding the issues discussed in the classroom. An example of an expression: A child who is a partner in the cognition process is active, independent, and asks a lot of questions. The children-treated as cognitive partner in the education process— have the opportunity to express their own understanding of the world and reveal the rich interior of experiences and thoughts. According to the respondents, cognitive partnership manifests itself in the child's independence in 
planning and carrying out tasks as well as creating and reporting solutions to problems. Then the child has a sense of agency and independent learning.

The least frequent statements of the respondents (14 interviewees) at the same time contained descriptions of mutual relations between the teacher and the child based on cognitive partnership.

Table 3. Response categories defining the concept of cognitive partnership as teacher-child relationship

\begin{tabular}{|c|c|c|}
\hline & Response categories & $\begin{array}{l}\text { Number of } \\
\text { indications }\end{array}$ \\
\hline \multirow{5}{*}{$\begin{array}{l}\text { Features of } \\
\text { the teacher-child } \\
\text { relationship }\end{array}$} & dialogue with children & 15 \\
\hline & $\begin{array}{l}\text { friendly mutual relations based on respect for autonomy, } \\
\text { freedom of action and a sense of security }\end{array}$ & 15 \\
\hline & joint problem solving with the child & 12 \\
\hline & $\begin{array}{l}\text { child's participation in the selection of methods and forms of } \\
\text { learning and the assessment of learning outcomes }\end{array}$ & 10 \\
\hline & discovering and constructing knowledge together & 7 \\
\hline
\end{tabular}

Source: Author's own elaboration based on the results of the research.

In a manner similar to the way the concept is defined in theoretical studies, the discussed group of respondents explained the concept of cognitive partnership using terms such as: relationship, relation or arrangement of relations between the teacher and children based on the sense of understanding and support from the interaction partner. According to the respondents, partnership in education is to ensure respect for one's own autonomy and freedom of action, as well as a sense of acceptance and security. The concept of cognitive partnership outlined in the statements by the teachers corresponds to the vision of the teacher-student relationship in line with the sociocultural concept, in the light of which the teacher becomes a partner in the child's development, "supports, structures, organizes, expands knowledge, enriches the child's efforts, knowledge and experiences in the field of specific competencies" (Filipiak 2008: 22) and adjusts the level of support to the current level of the child's activity. As Anna Brzezińska writes, "for this to be possible in the relationship between the teacher and the students, four elements must be in balance: the teacher's competencies, students' competencies, the requirements of the nature of challenges appropriate to both, and appropriate to the challenges as well as varied forms of support and assistance. Only then the system of mutual —unilateral, bilateral or multilateral - relations between the teacher and students and between the students themselves 
creates a truly stimulating social environment for both parties to develop" (Brzezińska 2008: 48). In the statements of the respondents (9 interviewees), it was difficult to find references to the teachers' creation of conditions for the development of a learning mechanism based on processes of mutual interaction, consisting in the exchange of meanings between interaction partners, i.e., the teacher and the student, and especially between the students themselves.

\section{Conclusion}

Cognitive partnership understood as "the equality of intellectual strategies, valuations and interpretations" (Klus-Stańska 2008: 69) of educational entities is one of the key factors determining the preparation of a child to the challenges posed by dynamically changing reality. Based on the conducted research, it can be concluded that when explaining the concept of cognitive partnership, the surveyed teachers most often focused unilaterally either on the teacher's activities or on the child's activities that indicate cognitive partnership. In the teacher's understanding of cognitive partnership in education, one can clearly see a tendency to emphasize the role and competencies of the teacher, whose task is primarily to personalize the education process and create conditions for building an educational space marked by a child's sense of security and enabling the child's activity and independence. In turn, in the case of children, the main manifestation of cognitive partnership is their behavior characterized by a high level of activity in classes, independent thinking and a high level of cognitive attitude. Much less frequently, the respondents' statements revealed the understanding of the concept in question as a relationship between two equal subjects of education, who co-decide about the course and effects of the education process. Few of the respondents indicated the key role of dialogue in the teacher-student relationship. A partner adult - in the opinion of only a few respondents-participates in the process of constructing knowledge by a child, does not impose meanings. Worryingly, only a few respondents emphasized the importance of creating conditions for peer social interactions that can form the basis of negotiating meanings.

There is no doubt that the key role in understanding the essence of cognitive partnership by early childhood education teachers is played by the way they think about the mind and cognitive abilities of children. What is important in this process is the departure from the way of perceiving the student's mind as learning by imitation or as learning as a result of exposure to didactic activities and acquiring declarative knowledge in favor of perceiving a child who, like an adult, has more or less coherent "theories" not only about the world, but also about their own mind and how it works (Bruner 2006: 82-89). 
The fragmentary results of the presented research on the understanding of cognitive partnership and the declared place of it in early school education may be an inspiration to conduct further in-depth research on its meaning and forms of implementation in school practice.

\section{Bibliography}

Babbie E. (2008). Podstawy badań spotecznych, trans. W. Betkiewicz et al., Warszawa: Wydawnictwo Naukowe PWN.

Bałachowicz J. (2017). Edukacja wczesnoszkolna w procesie zmiany. Dyskurs standardów czy dyskurs wartości?, "Lubelski Rocznik Pedagogiczny”, vol. 36, no. 1, pp. 11-27.

Bruner J. (2006). Kultura edukacji, trans. T. Brzostowska-Tereszkiewicz, Kraków: Universitas.

Brzezińska A. (2008). Nauczyciel jako organizator spotecznego środowiska uczenia się, [in:] E. Filipiak (ed.), Rozwijanie zdolności uczenia się. Wybrane konteksty i problemy, Bydgoszcz: Wydawnictwo Uniwersytetu Kazimierza Wielkiego, pp. 35-50.

Corsaro W. (2015). The sociology of childhood, Los Angeles (CA): Sage.

Doroszewski W. (2000). Stownik jezyka polskiego, Warszawa: Wydawnictwo Naukowe PWN.

Dumont H., Istance D., Benavides F. (eds.) (2013). Istota uczenia się. Wykorzystanie wyników badań w praktyce, trans. Z. Janowska, Warszawa: ABC a Wolters Kluwer business.

Filipiak E. (2008). Uczenie się w klasie szkolnej w perspektywie socjokulturowej, [in:] E. Filipiak (ed.), Rozwijanie zdolności uczenia się. Wybrane konteksty i problemy, Bydgoszcz: Wydawnictwo Uniwersytetu Kazimierza Wielkiego, pp. 82-98.

Grochowalska M. (2012). Przyszli nauczyciele wczesnej edukacji wobec dyskursywności pedagogiki, [in:] J. Bałachowicz, A. Szkolak (eds.), Z zagadnień profesjonalizacji nauczycieli wczesnej edukacji w dobie zmian, Kraków: Wydawnictwo Libron, pp. 11-26.

Jurgiel A. (2009). O możliwościach poznawczych fenomenografii, "Pedagogika Kultury", vol. 5, pp. 97-104.

Klus-Stańska D. (2008). Między wiedza a wtadzą. Dziecięce uczenie się w dyskursach pedagogicznych, [in:] E. Filipiak (ed.), Rozwijanie zdolności uczenia się. Wybrane konteksty i problemy, Bydgoszcz: Wydawnictwo Uniwersytetu Kazimierza Wielkiego, pp. 59-73.

Klus-Stańska D. (2009a). Dyskursy pedagogiki wczesnoszkolnej, [in:] D. Klus-Stańska, M. Szczepska-Pustkowska (eds.), Pedagogika wczesnoszkolna. Dyskursy, problemy, rozwiqzania, Warszawa: Wydawnictwa Akademickie i Profesjonalne, pp. 25-78.

Klus-Stańska D. (2009b). Od niechęci wobec dziecięcej samodzielności myślenia do przekazu fikcji spotecznej, czyli edukacja dla niekompetencji, "Studia Pedagogiczne. Problemy Społeczne, Edukacyjne i Artystyczne" 2009, vol. 18, pp. 15-29.

Klus-Stańska (2019). Wiedza osobista uczniów jako punkt zwrotny $w$ teorii i praktyce dydaktycznej, “Kwartalnik Pedagogiczny”, vol. 64, no. 1(251), pp. 7-20.

Kocór M. (2018). Partnerstwo edukacyjne w szkole, "Edukacja - Technika - Informatyka", no. 2(24), pp. 266-272. 
Lemańska-Lewandowska E. (2013). Nauczyciele a dyscyplina w klasie szkolnej. Przekonania - Strategie - Kierunki zmian, Bydgoszcz: Wydawnictwo Uniwersytetu Kazimierza Wielkiego.

Lewowicki T. (1994). Przemiany oświaty: szkice o ideach i praktyce edukacyjnej, Warszawa: Wydawnictwo Akademickie „Żak”.

Męczkowska A. (2002). Od świadomości nauczyciela do konstrukcji świata spotecznego. Nauczycielskie koncepcje wymagań dydaktycznych a problem rekonstrukcji kompetencji ucznia, Kraków: Oficyna Wydawnicza „Impuls”.

Mendel M. (2009). Nauczyciel z uczniem, rodzicami i lokalna spotecznościa. Koncepcje partnerstwa edukacyjnego, [in:] D. Klus-Stańska, M. Szczepska-Pustkowska (eds.), Pedagogika wczesnoszkolna - dyskursy, problemy, rozwiąania, Warszawa: Wydawnictwa Akademickie i Profesjonalne, pp. 186-223.

Michalak R. (2011). Poznawanie świata przyrody jako kontekst rozwoju kompetencji poznawczych trzecioklasistów, [in:] H. Sowińska (ed.), Dziecko w szkolnej rzeczywistości. Zatożony a rzeczywisty obraz edukacji elementarnej, Poznań: Uniwersytet im. Adama Mickiewicza w Poznaniu, pp. 129-170.

Milerski B., Śliwerski B. (eds.) (2000). Pedagogika. Leksykon, Warszawa: Wydawnictwo Naukowe PWN.

Nelson K. (2007). Young minds in social worlds: Experience, meaning, and memory, Cambridge (MA): Harvard University Press.

Neuman W.L. (1994). Social research methods: Qualitative and quantitative approaches, Boston (MA): Allyn and Bacon.

Nowak J. (2007). Nauczyciel - mentor czy facylitator?, [in:] E. Sałata, S. Ośko (eds.), Wspótczesne problemy pedeutologii i edukacji, Radom: Wydawnictwo Instytutu Technologii Eksploatacji - Państwowy Instytut Badawczy, pp. 54-58.

Nowak-Łojewska A. (2017). Dziecięce konstrukcje świata w rozmowach z dorostymi, "Problemy Wczesnej Edukacji”, no. 1(36), pp. 54-64.

Obuchowski K. (2004). Kody umystu i emocje, Łódź: Wydawnictwo Wyższej Szkoły Humanistyczno-Ekonomicznej.

Ordon U., Gębora A.K. (2017). Partnerskie relacje rodziny i szkoty w tworzeniu optymalnych warunków procesu edukacji, "Pedagogika Przedszkolna i Wczesnoszkolna", vol. 5, no. 1(9), pp. 57-64.

Pikul-Białecka M. (2012). Narodziny i rozwój refleksji nad myśleniem, Kraków: Wydawnictwo Uniwersytetu Jagiellońskiego.

Robinson K., Aronica L. (2012). Uchwycić żywiot. O tym, jak znalezienie pasji zmienia wszystko, trans. A. Baj, Kraków: Wydawnictwo Element.

Silverman D. (2008). Interpretacja danych jakościowych. Metody analizy rozmowy, tekstu i interakcji, trans. M. Głowacka-Grajper, J. Ostrowska, Warszawa: Wydawnictwo Naukowe PWN.

Szymczak M. (1979). Stownik języka polskiego, vol. 2, Warszawa: Państwowe Wydawnictwo Naukowe.

Uszyńska-Jarmoc J. (2007). Od twórczości potencjalnej do autokreacji w szkole, Białystok: Wydawnictwo Uniwersyteckie Trans Humana. 
Uszyńska-Jarmoc J. (2018). Komu sprzyja szkota? Różnice w rozwoju kompetencji poznawczych $i$ spotecznych dzieci w mtodszym wieku szkolnym, "Psychologia Rozwojowa", vol. 13, no. 2, pp. 85-100.

Zwiernik J. (2015). Podejścia badawcze w poznawaniu wiedzy dziecka, "Teraźniejszość Człowiek - Edukacja”, vol. 18, no. 1(69), pp. 81-103.

\section{ADDRESS FOR CORRESPONDENCE}

Ewa Kochanowska

University of Bielsko-Biala

e-mail: ekochanowska@ath.bielsko.pl 